\title{
APAKAH PERKEMBANGAN FINANSIAL MEREDAM ATAU MEMPERBESAR DAMPAK SUATU KEJUTAN?
}

\author{
Meily Ika Permata \\ Ibrahim \\ Hidayah Dhini Ari ${ }^{1}$
}

\begin{abstract}
This paper analyzes the role of financial development on economic output in Indonesia. Using vector autoregressive method, the results confirm the positive impact of financial development on output growth. The interaction between the financial development and the shock either in financial or real sector shows that the financial development has a positive role to dampen the negative impact of the shock on the output growth, while strengthen the positive one. Another variable on the model, which significantly affect the output growth are excess money, term of trade, and the price. Compare to these variables, the marginal effect of financial development on output is smaller.
\end{abstract}

Keywords: Financial development, shock, output volatility, VAR.

JEL Classification: E44, 016

1 Meily Ika Pertama (meily@bi.go.id), Ibrahim (ibrahim@bi.go.id) and Hidayah Dhini Ari (dhini_ari@bi.go.id) are researchers in Economic Research Bureau, Directorate of Economic and Monetary Policy Research. The author thanks to Dr. Noer Azzam, Dr. Perry Warjiyo, Dr. Iskandar Simorangkir and other colleagues in DKM for the excellent input and suggestion. 


\section{PENDAHULUAN}

Stabilitas makroekonomi merupakan salah satu syarat perlu bagi kesinambungan pembangunan ekonomi. Oleh karena itu, upaya untuk memahami sumber-sumber instabilitas kondisi makroekonomi merupakan salah satu tantangan yang senantiasa mendapatkan perhatian penting dalam ranah ilmu ekonomi.

Peran sektor finansial dikaitkan dengan pertumbuhan ekonomi telah lama menjadi subyek penelitian, khususnya sejak Schumpeter (1912).² Sejak itu, studi yang dilakukan untuk menguji kaitan antara perkembangan sektor finansial dan pertumbuhan ekonomi terus dilakukan. Berdasarkan kajian terhadap berbagai penelitian yang telah dilakukan, hubungan antara perkembangan sektor finansial dan pertumbuhan ekonomi cenderung tidak konklusif.

Beberapa pandangan meyakini bahwa perkembangan sektor finansial akan mendorong pertumbuhan (diawali oleh Schumpeter, 1911 dan Gurley dan Shaw, 1955) karena sektor finansial dapat mengatasi permasalahan dalam kendala pembiayaan, berkontribusi pada pengalokasian sumber dayasecara lebih efisien, menyalurkan pembiayaan serta berbagai aktivitas lain yang terkait dengan risk sharing dan inovasi finansial,medium bagi transmisi kebijakan moneter (Cecchetti dan Krause, 2001 dan Krause dan Rioja, 2006), mengatasi permasalahan ketidaksempurnaan di pasar dana (imperfect capital market) (Bernanke dan Gertler (1989), Greenwald dan Stiglitz (1993) serta Kiyotaki dan Moore (1997).Pengembangan sektor finansial diyakini juga bahwa berperan positif dalam menurunkan volatilitas variabelvariabel makroekonomi (Dynan, Elmendorf dan Sichel (2006), Denizer, Iyigun, dan Owen (2002), Harvey dan Lundblad (2006),Aghion et. al (2005), Aghion et. al (2009), Cecchetti, Lagunes dan Krause (2006), serta Mendicino (2007)).

Namun, Bacchetta dan Caminal (2000), Easterly et al. (2002) dan Kuneida (2008), menunjukkan bahwa kendala dalam pembiayaan (financial constraint) dapat menjadi faktor yang menahan atau justru memperparah dampak kejutan yang terjadi di perekonomian. Sementara itu, Lopez dan Spiegel (2002), Denizer et al. (2002), Silva (2002), dan Tharavanji (2007) justru menemukan hubungan negatif antara perkembangan sektor finansial dan volatilitas pertumbuhan ekonomi. Peneliti lain seperti, Tiryaki (2003), Beck (2006) \& Guryal et al. (2007) tidak menemukan hubungan yang signifikan antara sektor finansial dan volatilitas pertumbuhan.

2 Schumpeter, J.A., 1911. The Theory of Economic Development.Cambridge, Mass: HarvardUniversity Press. 


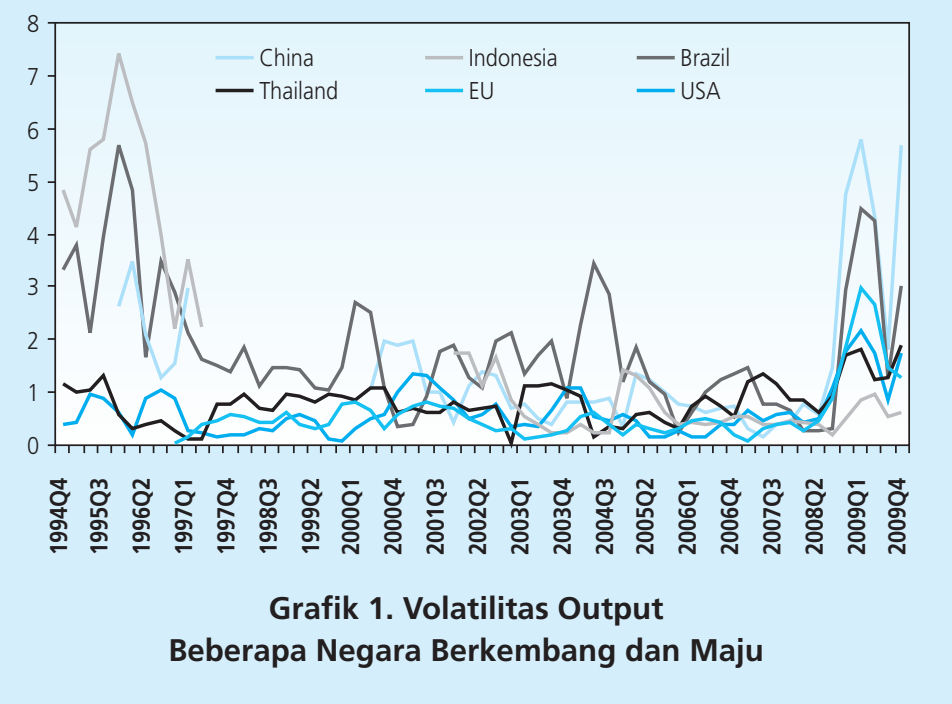

Berdasarkan gambaran di atas, dirasakan suatu kebutuhan untuk melakukan pengujian empiris tentang peran sektor finansial dalam stabilitas makroekonomi, khususnya pertumbuhan PDB, di Indonesia. Sebagai salah satu negara berkembang dengan sektor finansial yang masih terus berkembang, kajian terhadap peran sektor finansial dalam konteks stabilitas makroekonomi diharapkan dapat membantu arah perumusan kebijakan moneter yang lebih tepat. Apabila dibandingkan dengan beberapa negara maju, volatilitas output di beberapa negara emerging secara umum terlihat lebih tinggi, kecuali mulai periode krisis global (Grafik 1). Sementara itu, apabila dibandingkan dengan beberapa negara emerging, volatilitas output Indonesia pascakrisis 1997 terlihat relatif lebih kecil.

Secara eksplisit, paper ini mengidentifikasi hubungan antara peran sektor finansial dan volatilitas output di Indonesia. Indikator yang digunakan untuk mengukur perkembangan sektor finansial adalah rasio kredit kepada sektor swasta terhadap GDP. Ukuran ini lazim digunakan dalam penelitian-penelitian yang dilakukan sebelumnya. Pemahaman mengenai hubungan antara perkembangan sektor finansial dalam peranannya terhadap stabilitas makroekonomi diharapkan dapat menjadi suatu bahan masukan yang berharga dalam memformulasikan kebijakan moneter yang lebih baik.

Bagiankeduadari paper ini mengulas teori dan tinjauan literatur, bagian ketiga mengulas metodologi dan model empiris yang digunakan, sementara hasil dan analisis diuraikan pada bagian keempat. Kesimpulan, implikasi dan rekomendasi kebijakan akan diberikan pada bagian penutup. 


\section{TEORI}

Pandangan bahwa perkembangan sektor finansial akan mendorong pertumbuhan (diawali oleh Schumpeter, 1911 dan Gurley dan Shaw, 1955) disebabkan karena sektor finansial dapat mengatasi permasalahan dalam kendala pembiayaan. Selain itu, keberadaan sektor finansial berkontribusi pada pengalokasian sumber daya, baik finansial maupun nonfinansial, secara lebih efisien. Semakin dalam dan berkembangnya sektor finansial mampu meredam volatilitas dalam perekonomian, melalui kemampuannya dalam menyalurkan pembiayaan serta berbagai aktivitas lain yang terkait dengan risk sharing dan inovasi finansial.

Kontribusi sektor finansial dalam menstabilkan kondisi makroekonomi secara umum juga terjadi melalui kemampuannya untuk menjadi medium bagi transmisi kebijakan moneter (Cecchetti dan Krause, 2001 dan Krause dan Rioja, 2006). Bernanke dan Gertler (1989), Greenwald dan Stiglitz (1993) serta Kiyotaki dan Moore (1997) menghasilkan studi yang mengkorfimasi pandangan di atas, dengan menunjukkan bahwa sektor finansial berkontribusi mengatasi permasalahan ketidaksempurnaan di pasar dana (imperfect capital market), dan dengan demikian mengurangi volatilitas output di perekonomian.

Dynan, Elmendorf dan Sichel (2006) dan Denizer, lyigun, dan Owen (2002) serta Beakaert, Harvey dan Lundblad (2006) menyajikan hasil studi yang menunjukkan bahwa pengembangan sektor finansial berperan positif dalam menurunkan volatilitas variabel-variabel makroekonomi. Aghion et. al (2005) dan Aghion et. al (2009) mengkonfirmasi bahwa kendala dalam pembiayaan kredit berkontribusi memperbesar dampak kejutan di perekonomian melalui pilihan terhadap jenis investasi yang dilakukan pelaku usaha. Cecchetti, Lagunes dan Krause (2006) serta Mendicino (2007) membuktikkan bahwa kredit konsumsi berperan positif dalam mengatasi kendala likuiditas di tingkat rumah tangga sehingga dapat membantu menurunkan volatilitas pertumbuhan ekonomi.

Namun, Bacchetta dan Caminal (2000) menunjukkan bahwa kendala dalam pembiayaan (financial constraint) dapat menjadi faktor yang menahan atau justru memperparah dampak kejutan yang terjadi di perekonomian, tergantung pada jenis kejutan yang terjadi di perekonomian. Senada dengan Bacchetta dan Caminal, Easterly et al. (2002) dan Kuneida (2008) menemukan sifat hubungan antara perkembangan sektor finansial dan pertumbuhan ekonomi yang cenderung nonlinear. Dalam hal ini, perkembangan sektor finansial akan menurunkan volatilitas makroekonomi sampai pada titik tertentu, namun melewati titik tersebut kredit ke sektor swasta yang terlalu banyak justru akan meningkatkan volatilitas.

Sementara itu, Lopez dan Spiegel (2002), Denizer et al. (2002), Silva (2002), dan Tharavanji (2007) justru menemukan hubungan negatif antara perkembangan sektor finansial dan volatilitas 
pertumbuhan ekonomi. Yang lebih menarik, Tiryaki (2003), Beck (2006) dan Guryay et al. (2007) tidak menemukan hubungan yang signifikan antara sektor finansial dan volatilitas pertumbuhan.

Berdasarkan beberapa kesimpulan yang dapat ditarik dari model di atas, maka terlihat bahwa hubungan antara perkembangan finansial dan volatilitas output akan bersifat ambigu (tidak konklusif). Sifat hubungan tersebut akan tergantung pada kejutan yang muncul di perekonomian, apakah berasal dari sektor riil atau moneter, dan bagaimana suatu perekonomian merespon kejutan yang muncul tersebut.

Salah satu model sederhana tentang perkembangan sektor keuangan dibangun oleh Bacchetta dan Caminal (2000), dan kemudian dikembangkan dan dimodifikasi oleh Beck (2006). Dasar pemikiran model dibangun dari asumsi perekonomian yang terdiri dari konsumen (consumers) dan pengusaha (entrepreneurs). Setiap pengusaha memiliki akses yang sama terhadap teknologi produksi, yang diwakili oleh $f(k)$, dengan $f(0)=0, f^{\prime}(k)>0$, dan $f^{\prime \prime}(k)<$ 0 . Meskipun setiap pengusaha memiliki akses yang sama terhadap teknologi produksi, pada dasarnya pengusaha memiliki tingkat kekayaan (wealth) $b$ yang berbeda-beda. Sebanyak $\beta$ rasio dari pengusaha adalah pengusaha dengan kekayaaan tinggi (High). Dan sebanyak (1- $\beta$ ) rasio dari pengusaha adalah dengan kekayaan rendah (Low). High diasumsikan dapat memenuhi kebutuhan pembiayaan investasinya dan memiliki kelebihan dana yang disimpan di bank dan mendapat tingkat bunga $r^{D}$. High diasumsikan tidak memiliki kendala pembiayaan di pasar finansial, dan dengan demikian maksimisasi profit High tercapai pada :

$$
f^{\prime}\left(k^{H}\right)=r^{D}
$$

Sementara itu, Low memiliki keterbatasan pembiayaan sehingga harus meminjam dana dengan tingkat bunga $r^{D}$. Adanya assymetric information dan potensi moral hazard menyebabkan Low dikenakan agency $\operatorname{cost} \varphi$. Dengan kondisi ini, maksimisasi profit Low tercapai pada :

$$
f^{\prime}\left(k^{L}\right)=\varphi r^{L}, \varphi \geq 1
$$

Dengan demikian, marginal produktivitas relatif antara High dan Low adalah sebagai berikut :

$$
\frac{f^{\prime}\left(k^{L}\right)}{f^{\prime}\left(k^{H}\right)}=\varphi \frac{r^{L}}{r^{D}}
$$


Semakin besar perbedaan antara $r^{L}$ dan $r^{D}$ serta $\varphi$, maka semakin tinggi rasio $k^{H} / k^{L}$ dan semakin besar perbedaan marginal produktivitas antara Low dan High. Semakin tinggi $\varphi$, semakin besar efek realokasi dana antara High dan Low. Realokasi dana ini akan mempengaruhi produktivitas agregat dan akhirnya output perekonomian secara keseluruhan.

Pihak intermediari finansial, dalam hal ini bank, diasumsikan bekerja dalam kondisi persaingan sempurna, tanpa biaya, dan hanya memegang aset dalam bentuk pemberian kredit. Meskipun demikian, deposito dikenakan peraturan reserve requirement dari otoritas moneter, yaitu $\boldsymbol{\tau}$. Dengan demikian, kredit yang mampu diberikan bank kepada Low adalah sebesar $(1-\tau)$ dikalikan dengan deposito dari High. Kenaikan dengan demikian akan menurunkan dana yang tersedia untuk dipinjamkan kepada Low, dan sebaliknya. Agregat total pinjaman dari bank dengan demikian adalah :

$$
(1-\tau) \beta\left(b^{H}-k^{H}\right)=\left(k^{L}-b^{L}\right)(1-\beta)
$$

dimana $b^{H}$ adalah dana internal yang dimiliki High dan $k^{H}$ adalah tingkat investasi yang diinginkan High. Sedangkan $k^{L}$ dan $b^{L}$ masing-masing adalah tingkat investasi yang diinginkan dan dana internal Low. Adapun dana internal Low diasumsikan sangat kecil sehingga tidak bisa memenuhi tingkat investasi yang diinginkan.

Selanjutnya, dengan asumsi tidak adanya kemungkinan gagal bayar, maka rasio dari $r^{L}$ dan $r^{D}$ hanya dipengaruhi oleh besarnya reserve requirement, $\tau$, sehingga :

$$
\frac{r^{D}}{r^{L}}=(1-\tau)
$$

Dengan adanya assymetric information yang menghasilkan agency cost, maka Low secara natural akan selalu dihadapkan pada kondisi tingkat investasi yang sub-optimal. Hal ini berarti tingkat investasi yang mampu dilakukan akan selalu dibawah yang diinginkan. Agency cost dalam hal ini dinyatakan sebagai berikut :

$$
\varphi=\omega\left(1-\frac{b^{L}}{k^{L}}\right)
$$

dimana $\omega$ adalah fungsi dari sejumlah parameter teknologi yang bersifat eksogen. Hal ini berarti bahwa agency cost merupakan fungsi negatif linear dari rasio antara dana internal yang dimiliki dan tingkat investasi yang diinginkan Low. Semakin besar dana internal yang 
dimiliki, maka agency cost yang dibebankan bank kepada Low akan semakin kecil. Selanjutnya berdasarkan ini, maka :

$$
f^{\prime}\left(k^{L}\right)=r^{L} \omega\left(1-\frac{b^{L}}{k^{L}}\right)
$$

Persamaan (6) menunjukkan bahwa Low akan dihadapkan pada kondisi credit-constrained, sehingga tingkat investasi yang mungkin dicapai akan dibawah yang diinginkan. Tingkat investasi Low akan menurun dengan kenaikan $r^{L}, \omega$, dan rasio leverage $\frac{k^{L}}{b^{L}}$.

Berdasarkan persamaan-persamaan di atas, maka marjinal produktivitas dari High dan Low selanjutnya dapat dijabarkan dalam persamaan berikut :

$$
\frac{f^{\prime}\left(k^{L}\right)}{f^{\prime}\left(k^{H}\right)}=\omega\left(1-\frac{b^{L}}{k^{L}}\right) \frac{r^{L}}{r^{D}}=\omega\left(1-\frac{b^{L}}{k^{L}}\right)\left(\frac{1}{1-\tau}\right)
$$

Dengan demikian, kondisi market clearing di pasar finansial adalah sbb :

$$
\beta b_{t}^{H}+(1-\beta) b_{t}^{L}=\beta k_{t}^{H}+(1-\beta) k_{t}^{L}+\tau \beta\left(b_{t}^{H}-k_{t}^{H}\right)
$$

Berdasarkan (7) dan (8) dapat terlihat bahwa investasi relatif $k^{L} / k^{H}$ akan meningkat sejalan dengan meningkatnya rasio $b^{L} / k^{L}$ dan relatif rasio dana internal $b^{L} / b^{H}$ serta menurunnya agency cost $\omega$ dan reserve requirement $\tau$.

Berdasarkan persamaan-persamaan di atas maka diperoleh beberapa interpretasi hasil sebagai berikut:

1) Dampak dari kejutan yang terjadi pada sektor riil akan lebih besar pada kondisi assymetric information di pasar dana. Dampak itu akan makin besar sejalan dengan kenaikan pada agency cost $\omega$. Hal ini terlihat pada persamaan (7) dimana investasi yang dilakukan High akan lebih besar dari Low, sehingga menyebabkan marjinal produktivitas di Low lebih tinggi daripada High. Perbedaan marjinal produktivitas tersebut akan makin besar dengan semakin tingginya agency cost, suatu kondisi yang terdapat pada kondisi pasar dana yang diwarnai assymetric information. Dengan makin besarnya perbedaan marginal produktivitas, maka dampak dari kejutan kepada output perekonomian akan lebih besar.

2) Dampak dari kejutan yang berasal dari kebijakan moneter yang berpengaruh pada supply of loanable funds akan berdampak lebih kecil pada kondisi dimana terdapat assymetric 
information di pasar dana. Pelonggaran kebijakan moneter berupa penurunan tingkat reserve requirement $\tau$, akan menaikkan jumlah ketersediaan loanable loan yang pada akhirnya akan menurunkan $r^{L}$. Meskipun demikian, penurunan tingkat bunga akan menaikkan leverage dan akhirnya agency cost bagi Low. Hal ini pada akhirnya akan mengurangi sebagian dari dampak positif penurunan reserve requirement. Sementara itu, turunnya agency cost sebagai dampak dari semakin berkembangnya sektor finansial akan semakin menguatkan dampak positif penurunan reserve requirement ke output.

Inilah dasar hipotesis yang akan di uji dalam paper ini.

\section{METODOLOGI}

Penelitian ini akan menggunakan pendekatan ekonometrik guna menguji testable hypothesis dengan memanfaatkan metode vector auto regression (VAR). Metode VAR ini digunakan untuk melakukan pengujian dengan kasus Indonesia.

Model VAR merupakan suatu analisis fungsi linear dari pergerakan data di masa lampau yang dilakukankumpulanvariabel (variabel endogen) dalam suatu periode waktu yang sama $(\mathrm{t}=1, \ldots, \mathrm{T})$. Suatu model VAR $(\mathrm{p})$ dapat direpresentasikan dalam persamaan sebagai berikut :

$$
x_{t}=A_{0}+A_{1} x_{t-1}+A_{2} x_{t-2}+\ldots+A_{p} x_{t-p}+e_{t}
$$

dimana $e_{t}$ merupakan vektor dari error term yang memenuhi kondisi standar; $\mathrm{E}\left(\boldsymbol{e}_{t}\right)=0$, dan $\mathrm{E}\left(e_{t} e^{\prime}\right)=\Omega$.

Model VAR sangat sering digunakan dalam analisa makroekonomi. Namun demikian, meskipun pendekatan VAR mempunyai keunggulan dalam memodelkan dynamic behaviour dari variabel ekonomi dan forecasting, namun tak sedikit kritik yang ditujukan terhadap VAR berkaitan dengan pendekatannya yang cenderung bersifat atheoretical, dimana tidak adanya restriksi dalam struktur lag model VAR diasosiasikan sebagai tidak adanya struktur yang mendasari keterkaitan setiap variable dalam system VAR tersebut. Hal ini akan menimbulkan kesulitan dalam menginterpretasikan hasil.

Model teoritis yang diuraikan sebelumnya telah memberikan hipotesis yang akan diuji. Namun pengujian yang akan dilakukan tidak didasarkan pada bentuk reduced forms yang langsung diturunkan secara ekplisit dari model di atas, melainkan lebih bersifat empiris dan ditetapkan secara ad hoc dengan tujuan agar dapat mengakomodir beberapa variabel kontrol yang tidak tertangkap secara eksplisit dalam model. 
Beberapa variabel yang akan diikutsertakan dalam model adalah perkembangan PDB Riil dan pergerakan harga, guna menggambarkan volatilitas variabel makroekonomi. Selain itu diikutkan juga variabel di sektor riil dan moneter.Untuk sektor riil sebagai contoh dapat digunakan variabel terms of trade, sementara untuk sektor moneter dapat digunakan perkembangan excess money. adalah ukuran untuk perkembangan sektor finansial, yang dalam hal ini rasio kredit terhadap PDB. Sementara itu untuk menangkap adanya market imperfection/ assymetric information akan digunakan variable yang dapat menjelaskan adanya resiko seperti spread suku bunga kredit dan SBI.

Data yang digunakan pada penelitian ini merupakan data triwulanan dengan Periode triwulan pertama tahun 1997 sampai dengan triwulan kedua tahun 2010. Adapun rincian data yang digunakan adalah sebagai berikut :

1. PDB Riil : yang menggambarkan perkembangan output/pertumbuhan ekonomi

2. IHK : yang menggambarkan pergerakan harga

3. TOT : yang mewakili shock dari sektor riil

4. Excess Money : yang mewakili shock dari sektor moneter

5. Kredit/PDB : yang dipakai sebagai ukuran untuk perkembangan sektor finansial

6. Spread Suku Bunga SBI dan Kredit : yang menggambarkan besarnya resiko akibat adanya market imperfection/assymetric information

\section{HASIL DAN ANALISIS}

Secara umum, pergerakan indikator makroeknomi Indonesia pada awal periode pengamatan mengalami volatilitas yang relatif besar. Periode krisis tahun 1998 yang menyebabkan pertumbuhan ekonomi terkontraksi lebih dari 13,1\% dan inflasi yang melonjak mencapai 69,8\% diikuti oleh berbagai indikator lainnya seperti rasio kredit terhadap PDB, excess money, dan indikator risiko yang diwakili oleh indikator selisih suku bunga kredit dengan SBI (Grafik 5). Volatilitas berbagai indikator tersebut semakin membaik sejalan dengan membaiknya pengelolaan moneter. 


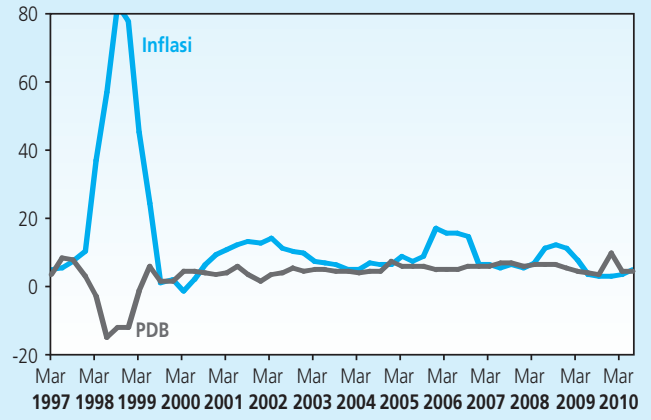

Grafik 2.

Perkembangan Indikator Utama

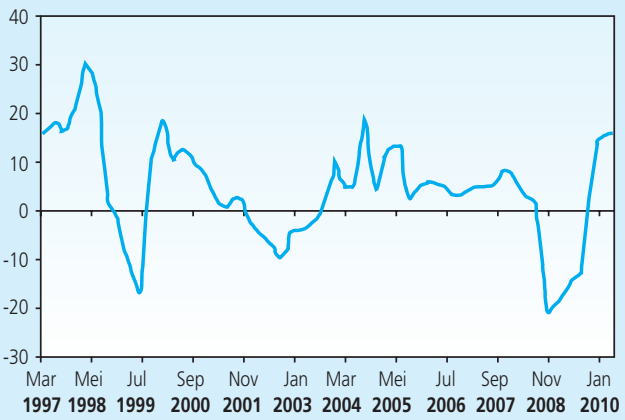

Grafik 4.

Excess Money

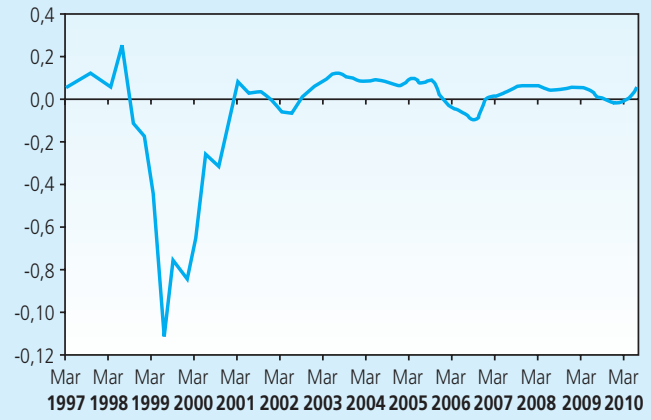

Grafik 3.

Pertumbuhan Finansial (dln FD)

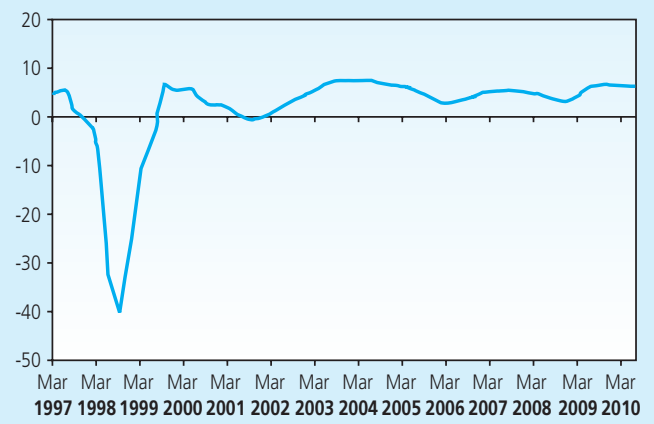

Grafik 5.

Spread Suku Bunga Kredit-SBI

Dari hasil pengamatan lebih detil dengan melihat pergerakan standard deviasi indikator makroekonomi dan finansial diperoleh gambaran pergerakan yang lebih jelas. Secara umum, gambaran volatilitas indikator PDB dengan variabel lainnya bergerak searah. Korelasi volatilitas pertumbuhan dengan rata-rata kredit/PDB mencapai $81 \%$ serta korelasi antara volatilitas pertumbuhan \& volatilitas inflasi sebesar 78\% (Grafik 6). Volatilitas dalam gambar tersebut di hitung dengan cara moving standard deviation selama tiga tahun untuk masing-masing indikator yang kemudian di hitung korelasi dari pasangan indikator yang diamati. Berdasarkan hipotesa awal adanya hubungan yang bergerak searah tersebut, dilakukan pengolahan data dengan menggunakan metode VAR. 

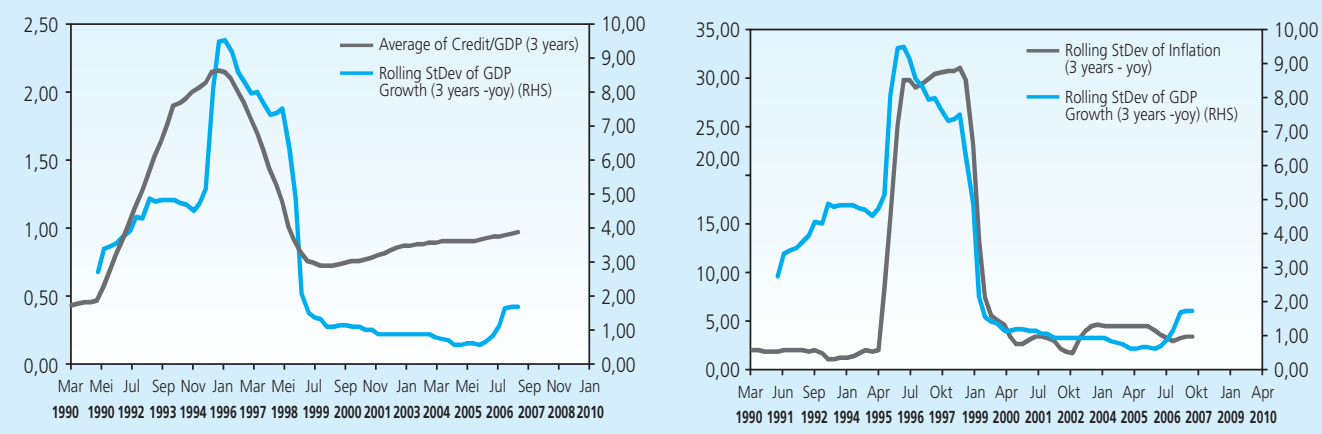

Grafik 6.

Perkembangan Keterkaitan Indikator Utama

Estimasi VAR diawali dengan melakukan stationary test terhadap setiap variabel dengan menggunakan Augmented Dickey Fuller (ADF) unit root test. Hasil uji indikator pengamatan menunjukkan bahwa variabel PDB dan IHK adalah non stationer pada level (tabel 1). Berdasarkan hasil uji unit root test, tersebut variabel- variabel yang dipilih untuk diikutsertakan dalam model VAR dalam kajian ini adalah dLnPDB, dLnIHK, dLnTOT, dLnFD, pertumbuhan risiko dan dan pertumbuhan excess money.

\begin{tabular}{l|c|}
\multicolumn{2}{c}{ Tabel 1.} \\
\multicolumn{1}{c|}{ Hasil Uji Unit Root Test } \\
PDB & Level (P-value) \\
dLnPDB & 1.0000 \\
Pertumbuhan PDB & 0.0967 \\
IHK & 0.0943 \\
dLnlHK & 0.8050 \\
Inflasi & 0.0006 \\
TOT & 0.3043 \\
dLnTOT & 0.0258 \\
Pertumbuhan TOT & 0.0020 \\
FD & 0.0057 \\
dLnFD & 0.0163 \\
Pertumbuhan FD & 0.0024 \\
Risk & 0.2049 \\
Pertumbuhan Resiko & 0.0000 \\
Pertumbuhan Excess Money & 0.0000 \\
\end{tabular}


Optimum lag order untuk prosedur VAR menunjukkan hasil yang mixed. Berdasarkan Schwartz Information Criteria lag yang optimal adalah 1, sementara Akaike Information Criteria dan Hannan Quinn Information Criteria menghasilkan lag optimal 6. Namun demikian, order lag 6 tidak dipilih dalam prosedur kajian ini mengingat jumlah observasi variabel hanya54. Kajian ini juga tidak mengikuti Schwart optimum lag dengan lag order 1, melainkan menetapkan penggunaan lag order 2 untuk dapat lebih baik mencakup dinamika variabel. Berdasarkan uji Lag Structure, diketahui bahwa estimasi VAR dengan lag order 2 bersifat stabil (stasioner) karena semua roots lebih kecil daripada 1 dan berada di dalam unit circle (Grafik 7).

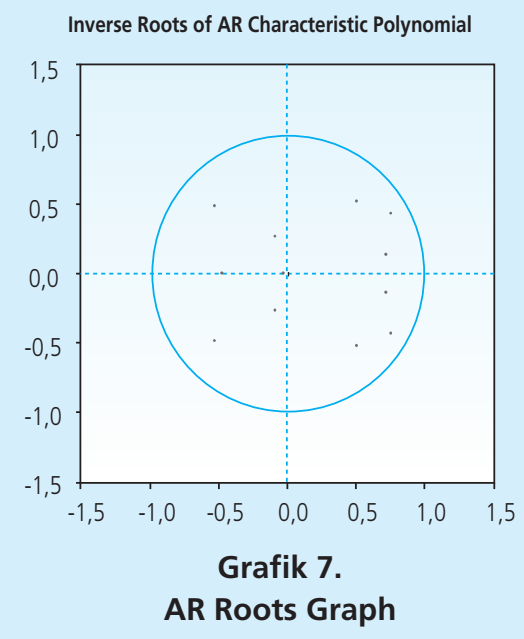

Hasil Granger Causality/Block Exogeneity Test menunjukkan bahwa secara bersamaan variabel pergerakan harga/inflasi, perkembangan TOT, pergerakan excess money, perkembangan finansial dan pergerakan resiko merupakan variabel penjelas pergerakan PDB (Tabel 2). Namun demikian, secara individu variabel perkembangan resiko kurang dapat menjelaskan pergerakan

Tabel 2.

VAR Granger Causality/Block Exogeneity Wald Tests

\begin{tabular}{|l|r|r|c|}
\multicolumn{1}{|c|}{ Excluded } & Chi-sq & df & Probability \\
DLNIHK & 17.48 & 2 & 0.000 \\
DLNTOT & 11.80 & 2 & 0.003 \\
EXCMON & 8.52 & 2 & 0.014 \\
DLNFD & 9.53 & 2 & 0.009 \\
GRISK & 1.09 & 2 & 0.580 \\
All & 56.73 & 10 & 0.000
\end{tabular}


PDB, namun tetap dipertahankan dalam model, mengingat variabel resiko menjadi variabel kontrol yang menggambarkan besarnya resiko akibat adanya market imperfection/assymetric information.

\subsection{Dampak Terhadap Pertumbuhan PDB}

Dari hasil impulse response mengenai dampak berbagai variabel terhadap PDB, terlihat bahwa perkembangan finansial berperan positif dalam meningkatkan pertumbuhan PDB dan signifikan pada triwulan 2 (Grafik 8). Sementara itu, terlihat bahwa kenaikan inflasi akan menurunkan pertumbuhan PDB secara signifikan selama 4 triwulan atau selama 1 tahun dari triwulan 2 sampai dengan triwulan 5. Peningkatan TOT juga secara signifikan akan menurunkan PDB selama 2 triwulan yaitu dari triwulan 2 sampai dengan triwulan 3. Selain itu, peningkatan excess money juga akan berdampak menurunkan PDB dan signifikan pada triwulan 2. Namun demikian, dampak peningkatan resiko akibat adanya market imperfection/assymetric information terhadap PDB cenderung tidak signifikan.
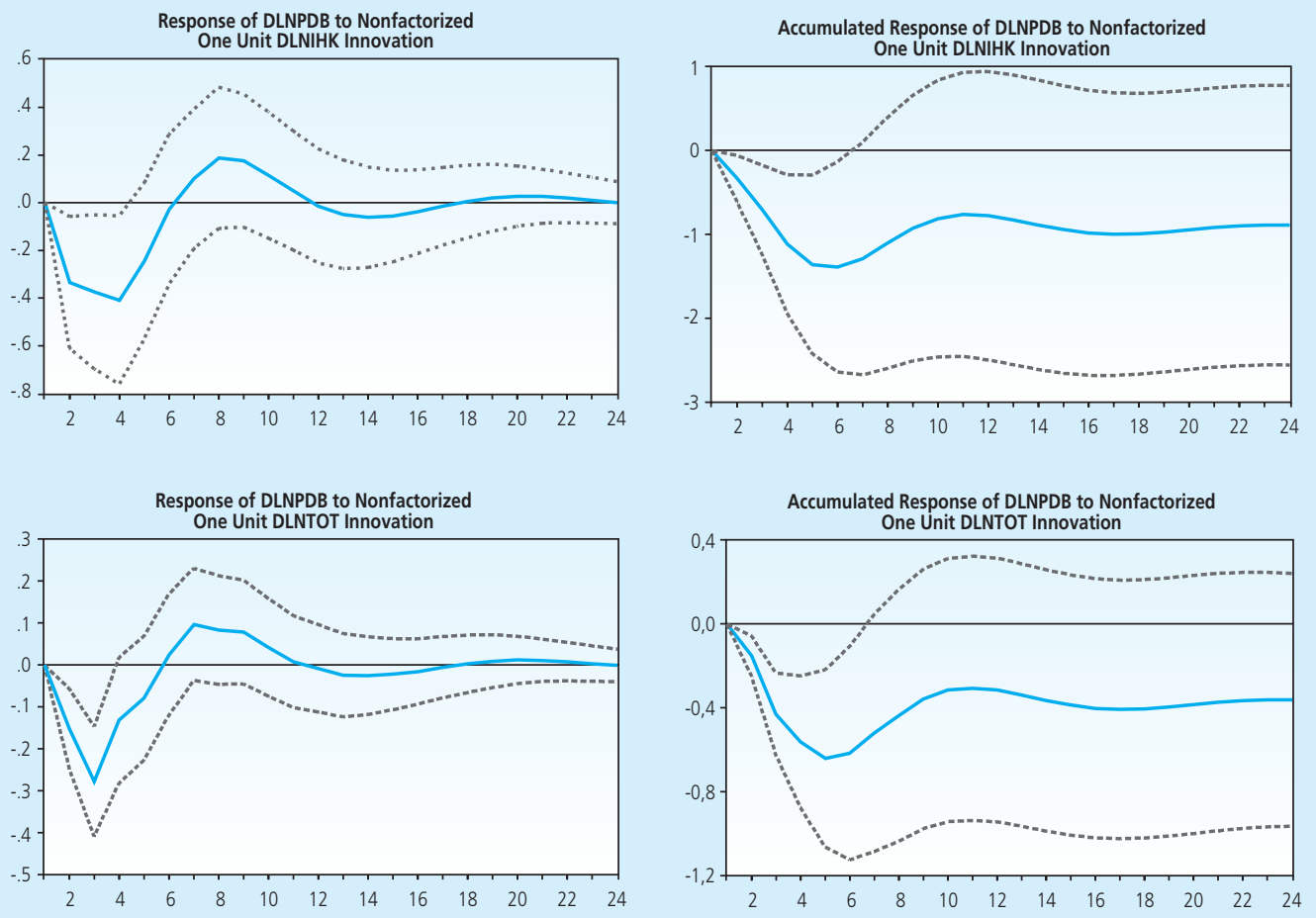

Grafik 8. Dampak Shock Inflasi, Perkembangan TOT, Pertumbuhan Excess Money, Perkembangan Finansial dan Perubahan Resiko Terhadap Pertumbuhan PDB 

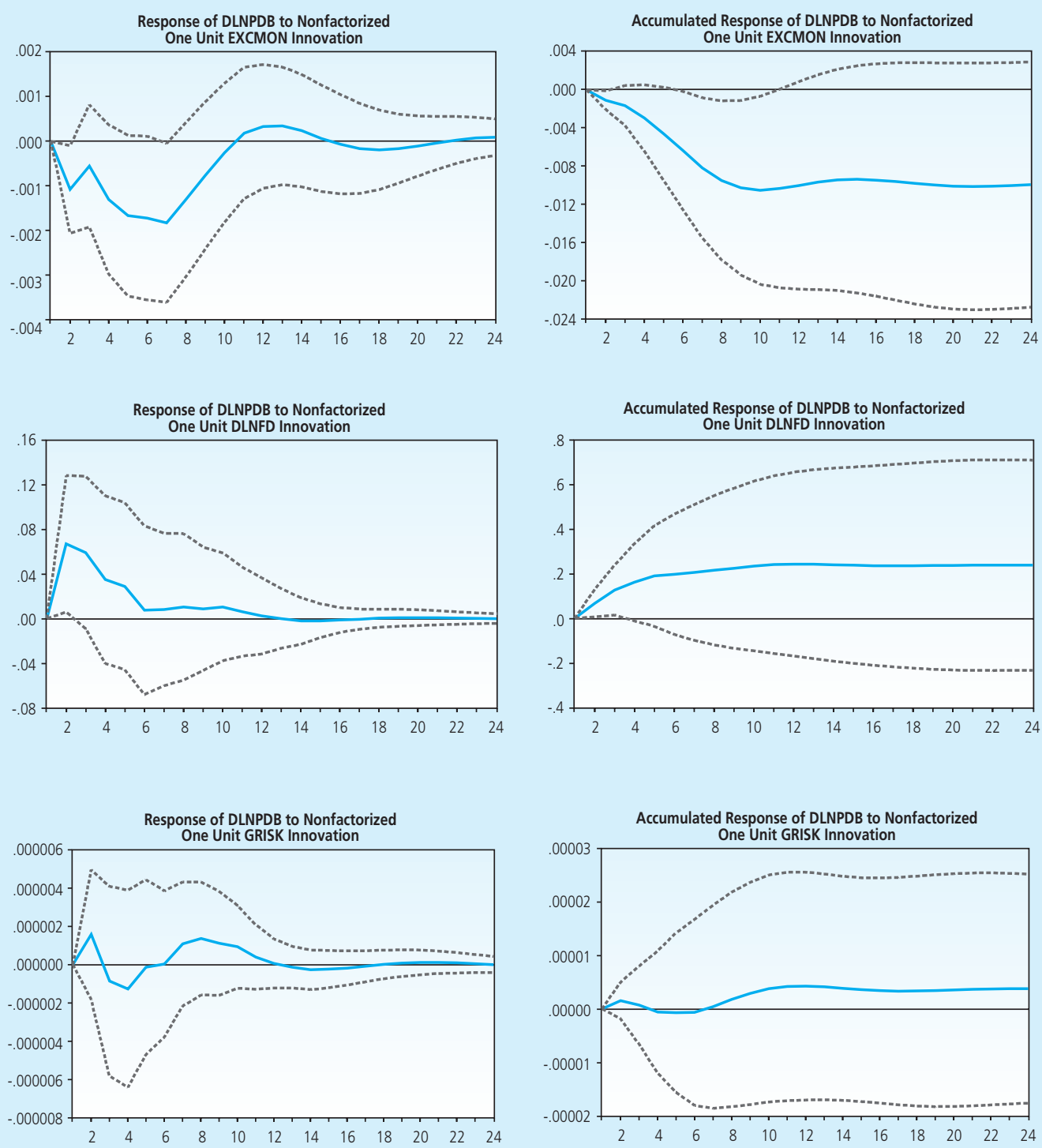

Grafik 8. Dampak Shock Inflasi, Perkembangan TOT, Pertumbuhan Excess Money, Perkembangan Finansial dan Perubahan Resiko Terhadap Pertumbuhan PDB (lanjutan)

Jika dilihat secara akumulasi, kenaikan inflasi, peningkatan TOT dan pertumbuhan excess money akan berdampak menurunkan pertumbuhan PDB. Sementara itu, secara akumulasi perkembangan finansial akan berdampak terhadap kenaikan PDB. Secara kumulatif, kenaikan perkembangan finansial sebesar $1 \%$ akan menyebabkan tambahan kenaikan PDB sebesar 2,4\% 


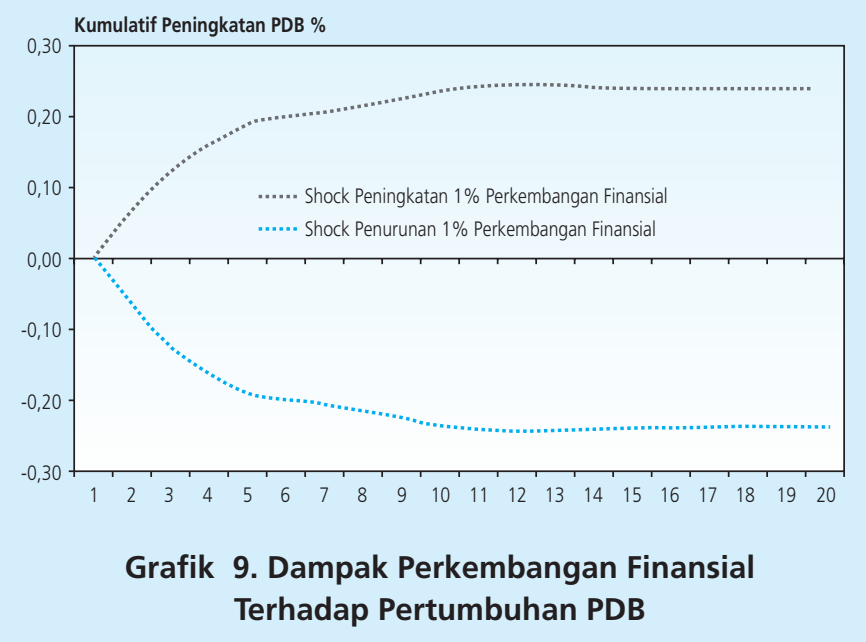

dalam kurun waktu 2,5 tahun (Gambar 9). Sebaliknya, penurunan perkembangan finansial sebesar $1 \%$ akan menyebabkan terjadinya akumulasi penurunan PDB sebesar $2,4 \%$ dalam kurun waktu 2,5 tahun.

Lebih lanjut, dengan analisa variance decomposition, terlihat bahwa perkembangan excess money, perkembangan TOT dan pergerakan harga merupakan variabel yang berperan besar dalam menjelaskan pergerakan PDB dalam jangka panjang masing-masing sebesar 27\%, 11\% dan 9\% (Tabel 3). Sementara perkembangan finansial hanya berkontribusi sekitar 2,6\%. Sedangkan faktor resiko hanya berkontribusi kurang dari $1 \%$.

\begin{tabular}{c|c|r|r|r|r|r|c|}
\multicolumn{7}{c}{ Tabel 3. } \\
\multicolumn{7}{|c|}{ Variance Decomposition of DLNPDB } \\
Period & S.E. & DLNPDB & DLNIHK & DLNTOT & EXCMON & DLNFD & GRISK \\
\hline 1 & 0,026 & 100,000 & 0,00 & 0,000 & 0,000 & 0,000 & 0,000 \\
2 & 0,033 & 81,750 & 5,535 & 11,579 & 0,623 & 0,438 & 0,075 \\
3 & 0,040 & 70,384 & 8,575 & 13,504 & 6,495 & 0,374 & 0,669 \\
4 & 0,044 & 62,215 & 9,940 & 12,844 & 13,955 & 0,423 & 0,622 \\
5 & 0,046 & 56,466 & 10,170 & 11,625 & 20,609 & 0,574 & 0,555 \\
6 & 0,048 & 52,796 & 9,954 & 10,869 & 24,969 & 0,876 & 0,536 \\
7 & 0,049 & 50,784 & 9,659 & 10,685 & 27,004 & 1,308 & 0,560 \\
8 & 0,049 & 49,859 & 9,440 & 10,822 & 27,481 & 1,800 & 0,598 \\
9 & 0,050 & 49,475 & 9,314 & 10,998 & 27,326 & 2,262 & 0,624 \\
10 & 0,050 & 49,281 & 9,249 & 11,078 & 27,129 & 2,629 & 0,633 \\
\hline
\end{tabular}




\subsection{Dampak Terhadap Inflasi}

Perkembangan finansial dan peningkatan resiko akibat adanya market imperfection/ assymetric information tidak signifikan dalam mempengaruhi inflasi. Faktor yang signifikan dalam mempengaruhi inflasi adalah peningkatan TOT yang secara signifikan akan menaikkan inflasi selama 5 triwulan yaitu dari triwulan 2 sampai dengan triwulan 6 . Selain itu, peningkatan excess money juga akan berdampak menurunkan PDB dan signifikan selama 11 triwulan yaitu dari triwulan 2 sampai dengan triwulan 12. Hasil impulse response yang memperlihatkan akumulasi dampak, menunjukkan bahwa peningkatan TOT dan pertumbuhan excess money akan berdampak meningkatkan inflasi.
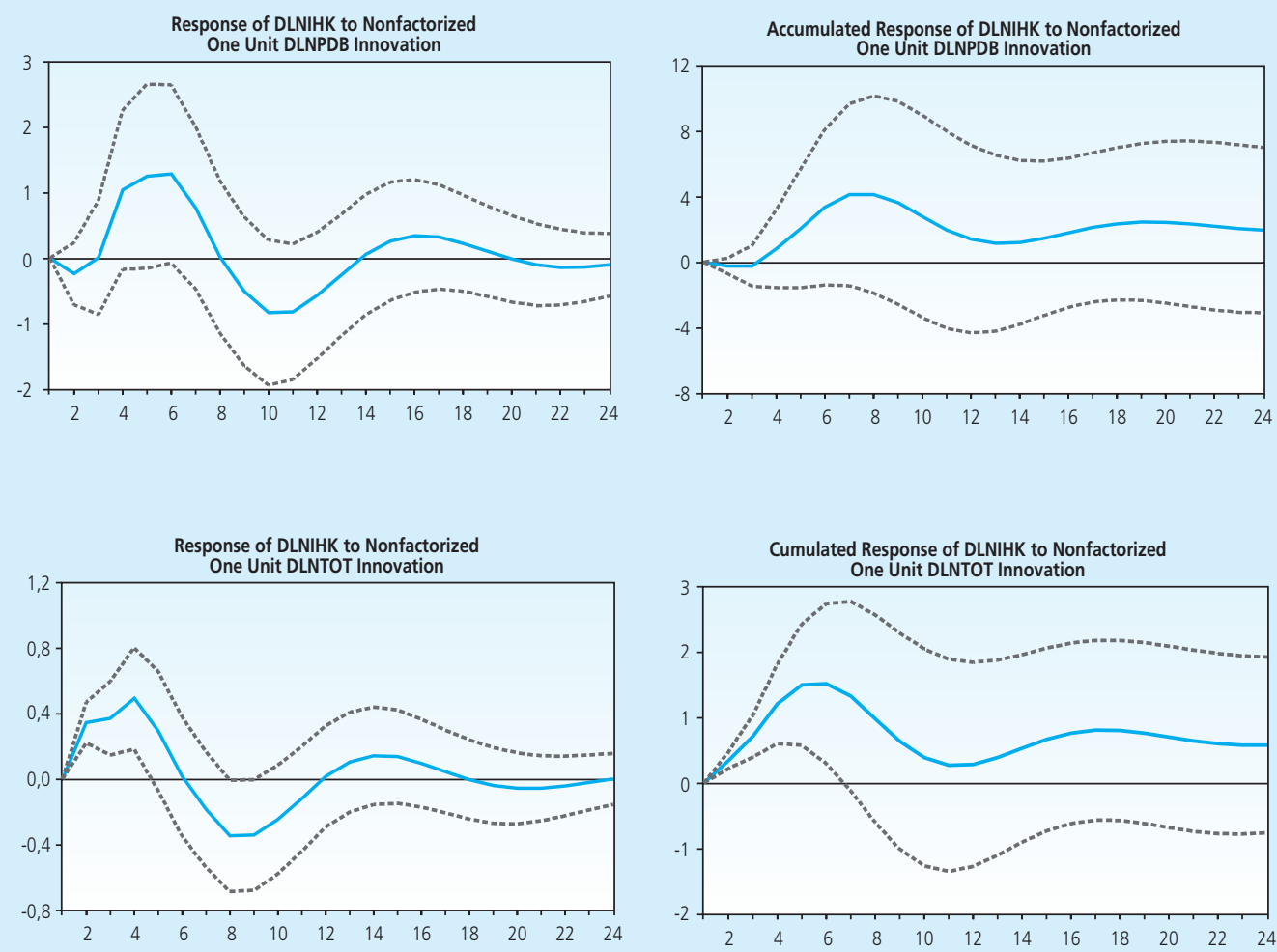

\section{Grafik 10.}

Dampak Shock Pertumbuhan PDB, Perkembangan TOT, Pertumbuhan Excess Money, Perkembangan Finansial dan Perubahan Resiko Respons Terhadap Inflasi 

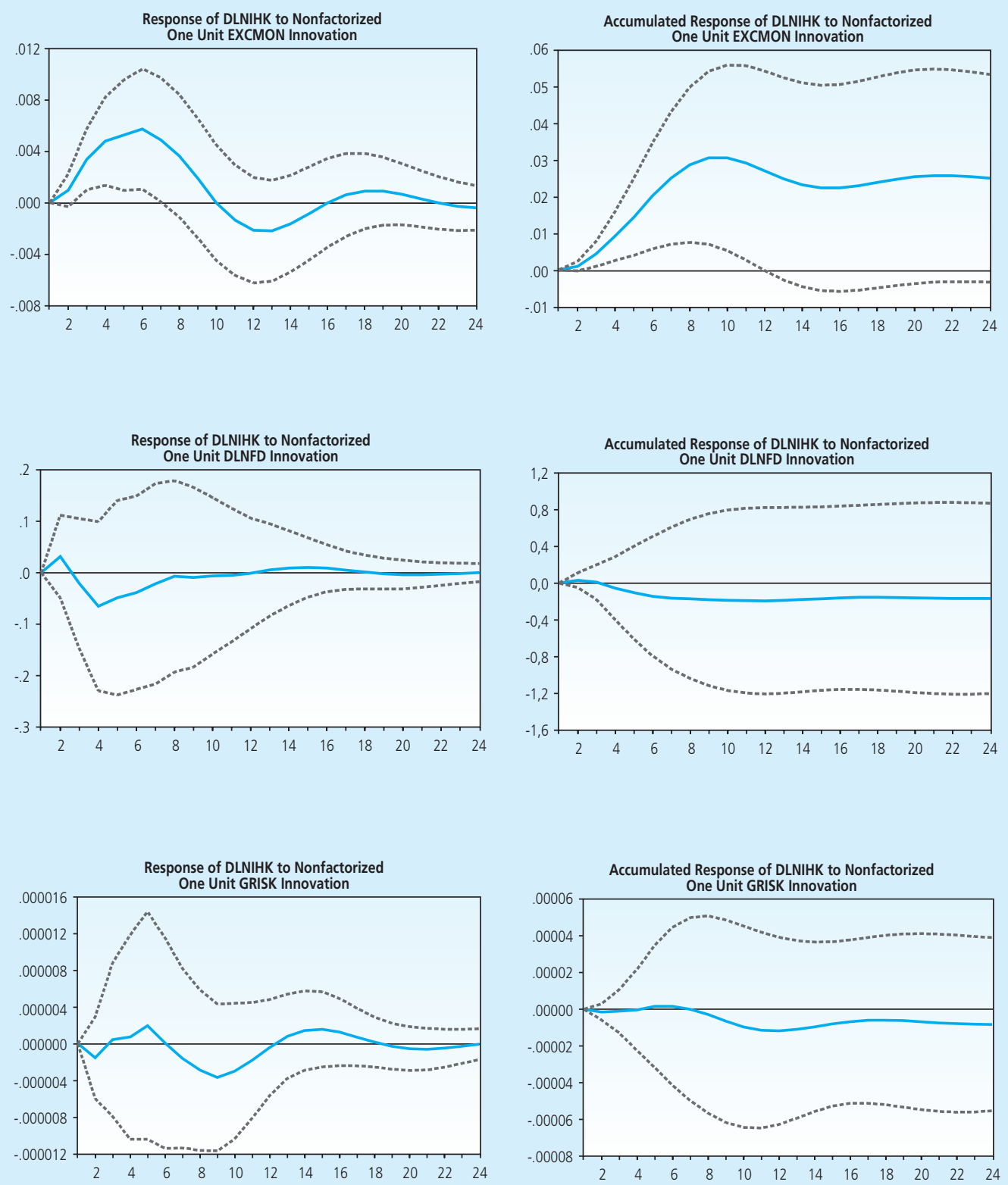

Grafik 10.

Dampak Shock Pertumbuhan PDB, Perkembangan TOT, Pertumbuhan Excess Money, Perkembangan Finansial dan Perubahan Resiko Respons Terhadap Inflasi (lanjutan) 
Hasil analisa variance decomposition untuk inflasi menunjukkan bahwa perkembangan excess money, perkembangan TOT dan pergerakan PDB merupakan variabel yang berperan besar dalam menjelaskan pergerakan inflasi dalam jangka panjang masing-masing sebesar 33\%, 21\% dan 19\% (Tabel 4). Sementara perkembangan finansial dan faktor resiko hanya berkontribusi kurang dari $1 \%$.

\begin{tabular}{c|c|c|r|r|r|r|r|}
\multicolumn{7}{c}{ Tabel 4.} \\
Period & S.E. & DLNPDB & DLNIHK & DLNTOT & EXCMON & DLNFD & GRISK \\
\hline 1 & 0,021 & 22,875 & 77,125 & 0,000 & 0,000 & 0,000 & 0,000 \\
2 & 0,032 & 42,434 & 38,577 & 17,416 & 1,221 & 0,058 & 0,293 \\
3 & 0,040 & 39,753 & 33,418 & 18,054 & 8,582 & 0,047 & 0,146 \\
4 & 0,045 & 29,168 & 32,137 & 22,651 & 15,769 & 0,164 & 0,111 \\
5 & 0,048 & 23,780 & 31,123 & 21,890 & 22,814 & 0,171 & 0,202 \\
6 & 0,049 & 21,424 & 28,777 & 19,244 & 30,189 & 0,189 & 0,177 \\
7 & 0,051 & 20,988 & 26,287 & 18,068 & 34,240 & 0,197 & 0,221 \\
8 & 0,052 & 20,345 & 25,022 & 18,978 & 35,073 & 0,197 & 0,385 \\
9 & 0,053 & 19,593 & 25,173 & 20,268 & 34,112 & 0,209 & 0,646 \\
10 & 0,053 & 19,030 & 25,862 & 20,954 & 33,133 & 0,216 & 0,804 \\
\end{tabular}

\subsection{Dampak Interaksi antara Perkembangan Finansial dengan Shock yang Terjadi di Sektor Riil (TOT) dan Moneter (Excess Money)}

Hasil impulse response yang menggabungkan interaksi antara shock di sektor riil dan moneter dengan perkembangan finansial menunjukkan bahwa perkembangan finansial mempunyai peranan positif dalam meredam dampak kejutan yang berpengaruh negatif terhadap pertumbuhan (Grafik 11 dan 12). Sebaliknya, perkembangan finansial akan membantu meningkatkan dampak kejutan yang positif terhadap pertumbuhan ekonomi.

Secara kumulatif, kenaikan TOT sebesar 1\% akan menurunkan PDB sebesar 0.4\% dalam waktu 4 tahun, namun apabila pada waktu yang bersamaan terjadi peningkatan perkembangan finansial sebesar 1\%, maka dampak kumulatif terhadap penurunan PDB dalam kurun waktu 4 tahun akan cenderung lebih kecil yaitu hanya sebesar 0,17\%. Sebaliknya, apabila terjadi penurunan TOT sebesar 1\%, maka secara kumulatif akan memberikan tambahan kenaikan PDB dalam kurun waktu 4 tahun sebesar 0.4\%. Namun apabila penurunan TOT sebesar $1 \%$ tersebut disertai dengan peningkatan perkembangan finansial sebesar $1 \%$ maka dampak kumulatif peningkatan PDB selama kurun waktu 4 tahun akan lebih tinggi lagi yaitu sebesar $0,64 \%$. 


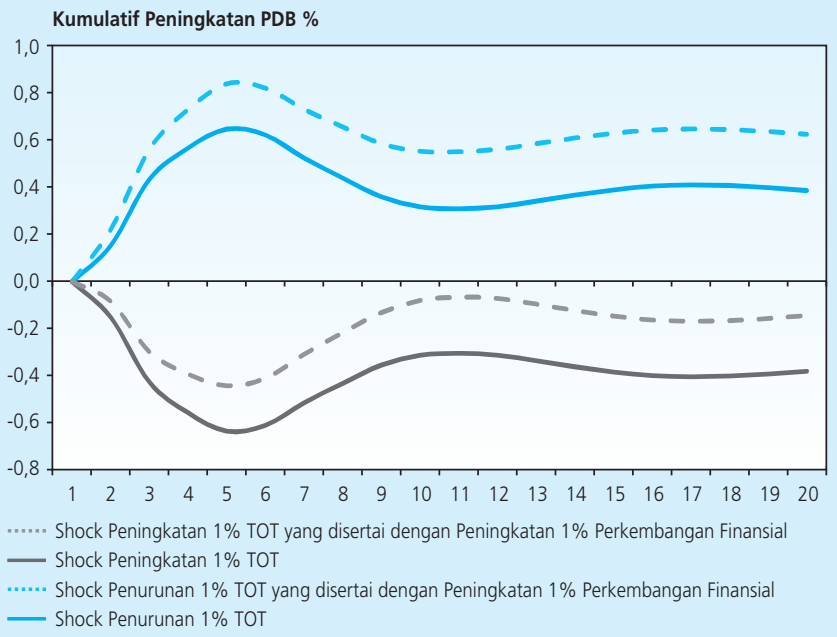

\section{Grafik 11. Dampak Interaksi Shock Perkembangan TOT dan Perkembangan Finansial Terhadap Pertumbuhan PDB}

Secara kumulatif, pertumbuhan 1\% excess money akan menurunkan PDB sebesar 1\% dalam waktu 2 tahun, namun apabila pada waktu yang bersamaan terjadi peningkatan perkembangan finansial sebesar $1 \%$, maka dampak kumulatif terhadap penurunan PDB dalam kurun waktu 2 tahun akan cenderung lebih kecil yaitu hanya sebesar 0,75\%. Sebaliknya, apabila

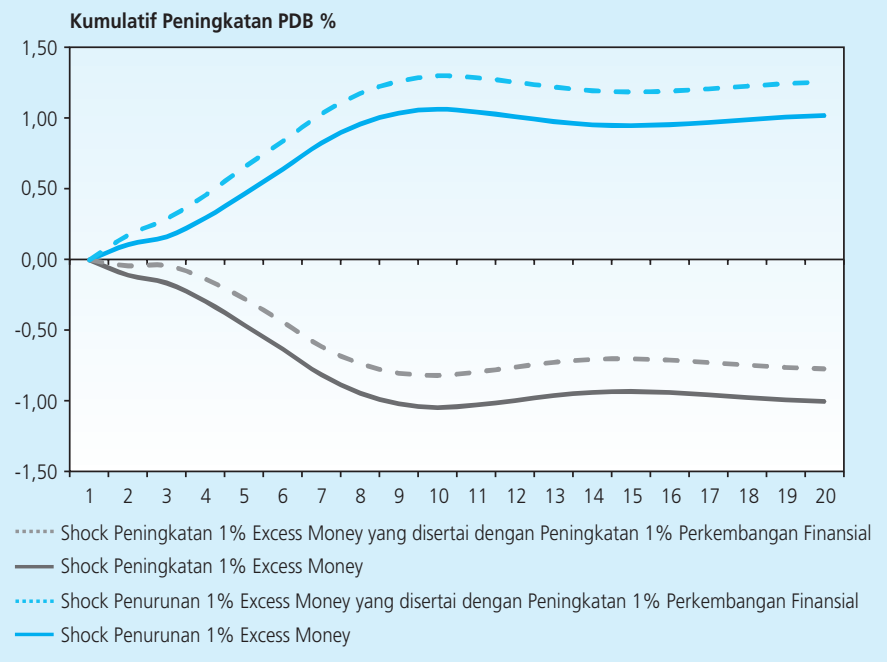

Grafik 12. Dampak Interaksi Shock Perkembangan Excess Money dan Perkembangan Finansial Terhadap Pertumbuhan PDB 
terjadi penurunan $1 \%$ excess money, maka secara kumulatif akan menaikkan PDB dalam kurun waktu 2 tahun sebesar $1 \%$. Namun apabila penurunan $1 \%$ excess money tersebut disertai dengan peningkatan perkembangan finansial sebesar $1 \%$ maka dampak kumulatif peningkatan PDB selama kurun waktu 2 tahun akan lebih tinggi lagi yaitu sebesar 1,25\%.

\section{KESIMPULAN}

Perkembangan finansial dan pertumbuhan ekonomi mempunyai hubungan yang positif, dimana semakin meningkatnya perkembangan finansial akan berdampak positif terhadap pertumbuhan ekonomi. Namun demikian, dampak dari peningkatan resiko akibat adanya market imperfection/assymetric information cenderung tidak signifikan terhadap PDB.

Interaksi antara shock di sektor riil dan moneter dengan perkembangan finansial menunjukkan bahwa perkembangan finansial mempunyai peranan positif dalam meredam dampak kejutan yang berpengaruh negatif terhadap pertumbuhan. Sementara itu, dampak kejutan yang positif terhadap pertumbuhan ekonomi akan semakin dikuatkan.

Beberapa faktor yang berpengaruh penting dalam pergerakan pertumbuhan dalam jangka panjang adalah perkembangan excess money, perkembangan TOT dan pergerakan harga. Sementara itu meskipun perkembangan finansial mempunyai peranan positif dalam perkembangan pertumbuhan ekonomi namun kontribusinya cenderung tidak terlalu besar dibanding faktor di atas. Perkembangan finansial dan peningkatan resiko akibat adanya market imperfection/assymetric information tidak signifikan dalam mempengaruhi inflasi sejalan dengan temuan bahwa perkembangan finansial dan faktor resiko tidak berkontribusi besar dalam menjelaskan pergerakan inflasi dalam jangka panjang. 


\section{DAFTAR PUSTAKA}

Bacchetta, Philippe \& Ramon Caminal (2000), "Do capital market imperfections exacerbate output fluctuations?". European Economic Review, No. 44, pp. 449-468.

Beck, Thorsten, Mattias Lundberg \& Giovanni Majnoni (2006), "Financial Intermediary Development and Growth Volatility: Do Intermediaries Dampen or Magnify Shocks?" . Journal of International Money and Finance, Volume 25, Issue 7, pp. 1146-1167.

Enders, Walter (2004), Applied Econometric Time Series, Wiley Series in Probability and Statistics. John Wiley \& Sons, Inc.

Greene, William H. (2008), Econometric Analysis. Prentice Hall.

Guryay, Erdal, okan Veli Safakli \& Behiye Tuzel. (2007). "Financial Development and Economic Growth: Evidence from Nothern Cyprus". International Research Journal of Finance and Economics, Issue 8.

Kuneida, Takuma (2008). "Financial Development and Volatility of Growth Rates : New Evidence". MPRA Paper No. 11341.

Schumpeter, J.A. (1911), The Theory of Economic Development, Cambridge, Mass. Harvard University Press.

Stock, J.H. dan M.W. Watson (2001), "Vector Autoregression". Journal of Economic Perspectives, 15,4 . 
134

Buletin Ekonomi, Moneter dan Perbankan, Oktober 2011

Halaman ini sengaja dikosongkan 